Sains Peternakan Vol. 6 (2), September 2008: 18-21

ISSN 1693-8828

\title{
Hubungan Antara Ukuran Indung Telur dengan Jumlah dan Mutu Sel Telur Sapi Brahman Cross
}

\author{
A. Taofik \\ Jurusan Peternakan - Fakultas Pertanian - Universitas bandung Raya \\ Jl. Cikutra No. 171 Bandung - Tlp./ Fax. 022-7202193 \\ Email :taofikunbar@yahoo.com
}

PENDAHULUAN

Perkembangan teknologi reproduksi seperti alih janin merupakan salah satu alat bantu manusia dalam meningkatkan mutu dan jumlah ternak dalam waktu yang relative singkat. Pemenuhan kebutuhan bahan alih janin dewasa ini dapat diperoleh melalui proses ferrtilisasi secara in vitro dan in vivo.

Melalui teknik fertilisasi in vivo, sangat sulit memprediksi berapa embrio yang dapat dihasilkan. Disamping itu, karena dalam teknik penyiapan sel telur untuk dibuahi melalui fertilisasi in vivo diawali dengan proses super ovulasi maka ternak betina yang menjadi sumber sel telur penggunaannya menjadi sangat terbatas.

Sebaliknya, dalam teknik fertilisasi in vitro, mutu sel telur yang dapat disediakan tergantung dari kemampuan keterampilan pelaksana penyedia sel telur, baik dalam memilih indung telur maupun menilai folikel yang diperkirakan berisi sel telur yang layak untuk dibuahi.

Ukuran indung telur yang besar memiliki lapisan luar yang lebih luas sehingga jumlah folikel yang terlihat lebih banyak dibandingkan dengan indung telur yang kecil. Perbedaan ukuran indung telur, salah satunya disebabkan adanya corpus luteum yang berkorelasi dengan keberadaan folikel yang membungkus sel telur. Indung telur yang memiliki lebih dari satu corpus luteum akan menghasilkan sel telur dengan mutu yang lebih baik.
Salah satu sumber potensial dalam memenuhi kebutuhan sel telur untuk fertilisasi in vitro adalah rumah potong hewan (RPH). Indung telur asal sapi yang dipotong di RPH memiliki ukuran yang bervariasi berhubungan dengan kondisi masing-masing sapi. Atas dasar hal tersebut, untuk kebutuhan praktis di lapangan dilakukan penelitian tentang Hubungan antara Ukuran Indung Telur dengan Jumlah dan Mutu Sel Telur Sapi Brahman Cross.

\section{BAHAN DAN METODE PENELITIAN}

\section{Bahan Penelitian}

Indung telur yang digunakan dalam penelitian ini adalah indung telur sapi Brahman Cross yang dipotong di RPH PT. Celmor Perdana Indonesia - Bogor. Sapi yang dipotong berumur antara $3-4$ tahun. Sapi yang digunakan sebagai sumber indung telur adalah yang memiliki indung telur lengkap (kanan dan kiri).

Bahan kimia yang digunakan terdiri dari Phosphate Buffer Saline (PBS), metal salt solution, Sodium Pyruvate, Glucose, Ultra Pure Water, antibiotic dan Ringer laktat.

\section{Peralatan Penelitian}

Peralatan penelitian yang digunakan terdiri dari mikroskop stereo, timbangan analitik, jangka sorong, pipet Pasteur, hot plate, cawan Petri, water bath, clean bench, syringe $5 \mathrm{ml}$, pinset, gunting bedah, pipet 
mikro ukuran $10-100 \mu \mathrm{l}$ dan $100-1000 \mu \mathrm{l}$ dengan tipnya, milipore $0,22 \mu \mathrm{m}$, gelas ukur 100 dan $600 \mathrm{ml}$, Erlenmeyer 100 dan $250 \mathrm{ml}$, parafilm dan kertas tissue.

\section{Metode penelitian}

\section{Prosedur Penelitian}

Pengambilan Indung Telur dari RPH. Indung telur dipisahkan dari jeroan segera setelah sapi di potong (sembelih). Hindarkan dari kontaminasi dengan kotoran sekitar tempat pemotongan. Indung telur dibersihkan dari jaringan lain yang menyelimuti bagian permukaannya, kemudian dicuci dengan Ringer Laktat. Masukkan indung telur ke dalam wadah plastic berisi Ringer Laktat yang mengandung antibiotic, kemudian wadah plastic dimasukkan ke dalam termos berisi air dengan temperature $38,5^{\circ} \mathrm{C}$. Kemudian dibawa ke laboratorium.

Pengamatan indung Telur. Segera setelah sampai di laboratorium, indung telur dicuci dengan Ringer Laktat, kemudian disimpan dalam gelas ukur. Ambil indung telur dengan pinset, kemudian keringkan dengan kertas tissue diatas meja preparat. Selanjutnya indung telur ditimbang dengan timbangan analitik. Pengukuran panjang, lebar dan ketebalan indung telur menggunakan jangka sorong.

Pengumpulan sel Telur. Sel telur dikumpulkan dari folikel yang berdiameter 2 - $6 \mathrm{~mm}$ dengan metode aspirasi atau penyedotan. Siapkan larutan PBS sebanyak 1 - 1,5 ml dalam syringe $5 \mathrm{ml}$ dengan jarum ukuran $18 \mathrm{G}$. Tusukkan jarum secara hati-hati ke dalam folikel, hisap dengan perlahan sampai folikel kemps kemudian beralih ke folikel lain hingga syringe berisi cairan sekitar $4 \mathrm{ml}$. Tuangkan cairan folikelke dalam cawan Petri yang bagian luar dasarnya telah diberi garis kotak berukuran $1 \mathrm{x} 1 \mathrm{~cm}$. Amati di bawah mikroskop stereo dengan perbesaran 40 kali.

\section{Variabel penelitian}

Bobot Indung Talue. Bobot indung telur diperoleh dari hasil penimbangan dengan menggunakan timbangan analitik. Bobot indung telur dinyatakan dalam gram.

Volume indung Telur. Volume indung telur diperoleh dari hasil perkalian panjang, lebar dan tebal indung telur. Pengukuran dimensi indung telur menggunakan jangka sorong. Volume indung telur dinyatakan dalam $\mathrm{cm}^{3}$.

Mutu Sel Telur. Hasil pengumpulan sel telur, selanjutnya dilakukan klasifikasi mutu sel telur berdasarkan kandungan cumulus ooporus sebagai berikut :

Mutu A. Seluruh permukaan sel telur dikelilingi cumulus ooporus

Mutu B. Sebagian permukaan sel telur dikelilingi cumulus ooporus

Mutu C. Sel telur tidak memiliki cumulus ooporus

\section{Analisis Data}

Metode penelitian yang digunakan dalam penelitian ini adalah metode deskriptif. Data yang diperoleh selanjutnya dianalisis dengan analisis regresi dan korelasi sederhana. Yang menjadi variable bebasnya adalah jumlah dan mutu sel telur, sedangkan variable terikatnya adalah ukuran indung telur yaitu bobot dan volume.

\section{HASIL DAN PEMBAHASAN}

\section{Struktur Data Pengamatan}

Bobot Indung Telur. Indung telur yang diamati dalam penelitian ini sebanyak 70 buah berasal dari 35 ekor sapi betina Brahman Cross berusia 3 sampai 4 tahun. Rataan bobot indung telur yang diperoleh adalah 15,47 gram, dengan kisaran 4,92 hingga 27,32 gram. Hafez (1993) mengemukakan bahwa bobot 
ovarium sapi berkisar antara 10 hingga 20 gram.

Volume Indung Telur. Volume indung telur yang diperoleh dalam penelitian ini berkisar antara 8,37 hingga $33,89 \mathrm{~cm}^{3}$ dengan rataan $20,85 \mathrm{~cm}^{3}$.

Jumlah dan mutu Sel Telur. Secara keseluruhan, rataan jumlah sel telur yang diperoleh dari setiap indung telur adalah 12,71 buah, dengan kisaran antara 6 hingga 20 sel telur. Hafez (1993) menjelaskan bahwa jumlah folikel de Graaf matang dalam setiap indung telur dalam suatu siklus reproduksi berkisan antara $1-2$ sel. Rataan sel telur yang diperoleh berdasarkan mutunya, mutu $\mathrm{A}$ 4,41 buah $(34,70 \%)$; mutu B 3,74 buah $(29.42 \%)$ dan mutu C 4,55 buah $(35,80 \%)$.

\section{Hubungan antara Ukuran Indung Telur dengan Jumlah dan Mutu Sel Telur}

Hubungan antara Bobot Indung Telur dengan Jumlah dan Mutu Sel Telur. Berdasarkan hasil perhitungan statistic, hubungan antara bobot indung telur dengan mutu sel telur pada sapi Brahman Cross, disajikan pada Tabel 1.

Tabel 1. Hasil perhitungan Analisis Regresi Hubungan antara Bobot Indung Telur dengan Jumlah dan Mutu Sel Telur

\begin{tabular}{|c|c|c|c|c|}
\hline \multirow{2}{*}{$\begin{array}{l}\text { Komponen } \\
\text { Perhitiungan }\end{array}$} & \multicolumn{4}{|c|}{ Sel Telur } \\
\hline & Mutu A & Mutu B & Mutu C & Total \\
\hline Intersep & 11,51 & 1,29 & 13,53 & 7,04 \\
\hline $\mathrm{X}_{1}$ & 0,89 & 0,15 & 0,42 & 0,66 \\
\hline $\begin{array}{l}\text { Persamaan } \\
\text { regresi }\end{array}$ & $11,51+0,89 x$ & $1,29+0,15 x$ & $13,53+0,42 \times$ & $7,04+0,66 x$ \\
\hline $\begin{array}{l}\text { Koefisien } \\
\text { Determinasi }\end{array}$ & 0,43 & 0,05 & 0,17 & 0,45 \\
\hline $\begin{array}{l}\text { Koefisien } \\
\text { Korelasi }\end{array}$ & 0,19 & 0,003 & 0,03 & 0,20 \\
\hline
\end{tabular}

Berdasarkan hasil analisis tersebut, terlihat bahwa bobot indung telur menentukan jumlah sel telur total sebesar $45 \%$, dan sel telur dengan mutu A sebesar $43 \%$. Terdapat hubungan positif antara bobot indung telur, baik dengan jumlah sel telur total maupun dengan mutu sel telur. Hal ini menunjukkan bahwa semakin tinggi bobot indung telur, maka jumlah sel telur yang dikandungnya semakin banyak. Berdasarkan interpretasi koefisien korelasi, menurut sugiyono (2000), nilai koefisien korelasi sebesar 0,19 dikatagorikan sangat lemah. Berdasarkan hal tersebut, mutu sel telur tidak dapat ditaksir berdasarkan bobot indung telur.
Hubungan antara Volume Indung Telur dengan Jumlah dan Mutu Sel Telur. Hasil perhitungan statistic, hubungan antarta volume indung telur dengan mutu dan jumlah sel telur pada sapi Brahman Cross disajikan pada Tabel 2.

Berdasarkan hasil analisis yang tertuang pada table 2, terlihat bahwa volume indung telur menentukan jumlah sel telur total sebesar $48 \%$ dan sel telur dengan mutu A sebesar $47 \%$. Terdapat hubungan positif antara volume indung telur, baik dengan jumlah sel telur total maupun dengan mutu sel telur, hadirnya corpus luteum pada indung telur menyebabkan volume indung telur bertambah. Toelihere (1981) menjelaskan bahwa volume indung telur 
dipengaruhi oleh corpus luteum dan volikel yang dimilikinya. Demikian pula pernyataan Boediono dkk., (1999) bahwa ukuran indung telur yang besar memiliki lapisan terluar yang lebih luas sehingga jumlah folike yang nampak lebih banyak. Perbedaan volume indung telur disebabkan adanya corpus luteum yang berkorelasi dengan keberadaan folikel yang membungkus sel telur.

Tabel 2. Hasil perhitungan Analisis Regresi Hubungan antara Volume Indung Telur dengan Jumlah dan Mutu Sel Telur

\begin{tabular}{|c|c|c|c|c|}
\hline \multirow{2}{*}{$\begin{array}{c}\text { Komponen } \\
\text { Perhitiungan }\end{array}$} & \multicolumn{4}{|c|}{ Sel Telur } \\
\hline & Mutu A & Mutu B & Mutu C & Total \\
\hline Intersep & 15,49 & 20,01 & 18,28 & 9,41 \\
\hline $\mathrm{X}_{1}$ & 1,21 & 0,22 & 0,56 & 0,89 \\
\hline $\begin{array}{l}\text { Persamaan } \\
\text { regresi }\end{array}$ & $15,49+1,21 x$ & $20,01+0,22 x$ & $18,28+0,56 x$ & $9,41+0,89 x$ \\
\hline $\begin{array}{l}\text { Koefisien } \\
\text { Determinasi }\end{array}$ & 0,47 & 0,07 & 0,18 & 0,48 \\
\hline $\begin{array}{l}\text { Koefisien } \\
\text { Korelasi }\end{array}$ & 0,22 & 0,004 & 0,03 & 0,23 \\
\hline
\end{tabular}

Nilai koefisien korelasi 0,22, menurut Sugiyono (2000), dikatagorikan rendah. Berdfasarkan hal tersebut, mutu sel telur tidak dapat ditaksir berdasarkan volume indung telur. Namun walaupun demikian, baik berdasarkan patokan bobot maupun volume indung telur, sel telur dengan mutu A dalam penelitian ini seiring dengan total sel telur yang diperoleh. Hal ini menunjukkan bahwa, agar diperoleh sel telur dengan mutu A, perlu memperhatikan diameter folikel yang akan diambil sel telurnya.

\section{KESIMPULAN DAN SARAN}

\section{Kesimpulan}

1. Terdapat hubungan positif baik antara bobot indung telur maupun volume indung telur dengan jumlah dan mutu sel telur

2. bobot indung telur dan volume indung telur tidak dapat dijadikan acuan untuk memprediksi kualitas sel telur yang dimiliki.

\section{Saran}

Perlu dilakukan penelitian lebih lanjut dengan jumlah sample yang lebih banyak dan bangsa sapi yang berbeda.

\section{DAFTAR PUSTAKA}

Boediono, A., Y, Usiantono, K. Mohaman, I. Djuwita dan Y. Sukra. 1999. Produksi Embrio Kambing dengan Teknologi Maturasi dan Kultur In Vitro. Prosiding Seminar Nasional Veteriner. Hal. : $258-263$

Hafez, E.S.E. 1993. Anatomy of Female Reproduction dalam Reproduction in farm Animal. E.S.E. Hafez (ed). Lea and Febiger. Hal. : $20-55$

Sugiyono. 2000. Statistika untuk Penelitian. CV. Alfabeta. Bandung

Toeliher, R.m. 1981. Fisiologi Reproduksi pada Ternak. Angkasa. Bandung. 